Chimia 46 (1992) 304-31)

(C) Neue Schweizerische Chemische Gesellschaft ISSN $0009-4293$

\title{
Peptidoleukotriene Antagonists State of the Art
}

\author{
Andreas von Sprecher*, Andreas Beck, Marc Gerspacher, and Michael A. Bray
}

Abstract. Peptidoleukotrienes ( $\mathrm{LTC}_{4}, \mathrm{LTD}_{4}$, and $\mathrm{LTE}_{4}$ ) have been proposed as important mediators of asthma. Twenty years of research in the field of peptidoleukotriene $(\mathrm{pLT})$ antagonists have generated a number of biologically active compounds from different structural classes. Several drugs have been or are currently in clinical trials. The first generation peptidoleukotriene antagonists (e.g. FPL 55712) showed disappointing results in asthmatic patients, due to insufficient potency. However, new classes of highly potent antagonists (e.g. ICI 204219) are proving successfull in clinical trials in asthma patients. Thus, peptidoleukotriene antagonists may represent a new principle in asthma therapy. In this paper, the in vitro potency and clinical data of different classes of peptidoleukotriene antagonists are reviewed.

\section{Introduction}

The peptidoleukotrienes $\mathrm{C}_{4}, \mathrm{D}_{4}$, and $\mathrm{E}_{4}\left(\mathrm{LTC}_{4}, \mathrm{LTD}_{4}, \mathrm{LTE}_{4}\right)$ are a class of local tissue hormones, which are involved in a number of regulatory processes. These endogeneous mediators are metabolites of arachidonic acid (AA), which is enzymatically liberated from membrane phospholipids (Scheme). The AA can be converted to prostaglandins, prostacyclin, and thromboxane via the cyclooxygenase pathway, which can be blocked by the so-called NSAIDs (Non-Steroidal Antiinflammatory Drugs) like diclofenac or indomethacin. Via a second pathway the AA can be transformed by the enzyme 5-lipoxygenase to the epoxide $\mathrm{LTA}_{4}$ which is the precursor both for leukotriene $\mathrm{B}_{4}\left(\mathrm{LTB}_{4}\right)$ and the peptidoleukotrienes (pLTs). LTB $_{4}$ is an important inflammatory mediator with potent chemotactic activity and may also act as a modulator of inflammatory cell function. $\mathrm{LTB}_{4}$ is implicated in various inflammatory diseases including psoriasis, inflammatory bowel disease, and rheumatoid arthritis.

\footnotetext{
*Correspondence: Dr. A. von Sprecher Research Department

Pharmaceuticals Division

Ciba-Geigy Ltd.

$\mathrm{CH}-4002$ Basel
}

In contrast, local production of pLTs is likely to be a major factor in the pathogenesis of asthma and related conditions. Constriction of bronchial smooth muscle and excessive production of bronchial mucus are characteristic symptoms evoked by pLTs, resulting in a decrease of lung volume associated with an asthma attack [1]. Consequently potent and selective pLT antagonists should be useful therapeutic agents for the treatment of this widespread disease.

After 1980, when the structures of the pLTs, previously collectively known as SRS-A (Slow-Reacting Substance of Anaphylaxis), became available, the pharmaceutical industry initiated ambitious research programs aimed at the development of pLT antagonists [2].

This review will exclusively discuss pLT antagonists which are or were in clinical trials, as well as some new and promising structures, likely to undergo clinical evaluation. A tabular format has been chosen, which allows for quick access to the relevant in vitro data and the status of clinical development for different structural classes of pLT antagonists.

\section{Hydroxyacetophenones: Analogs of FPL 55712 (Table I)}

The first pLT antagonist, FPL 55712, was described in 1973 [3], six years before the structures of the pLTs were elucidated.
For several years, FPL 55712 was practically the only lead in the search for pLT antagonists. A huge number of analogs, which share the hydroxyacetophenone residue linked by a carbon chain to an acidic group, were prepared. A small number of these were evaluated in clinical trials. Although some beneficial effects in humans could be shown (e.g. LY 171883), these first generation pLT antagonists in general proved to be not potent enough to be of clinical value. Today, they are no longer regarded as lead structures, and most companies have stopped research on this class of pLT antagonists.

\section{pLT Analogs (Table 2)}

Ever since the structures of the pLTs were defined by Samuelsson and Corey [4], a new area of pLT antagonist research evolved using the natural mediators as a starting point for chemical modification. Although this was a highly sophisticated enterprise, due to the chemical lability and the complicated nature of the lead structures, four antagonists of this type (SK\&F 104353, SK\&F 106203, LY 170680, CGP 45715A) have been identified for testing in humans. Interestingly, SK\&F 104353 and LY 170680 retain the same relative and absolute configuration of the chiral $\mathrm{OH}$ and thioether centers of $\mathrm{LTD}_{4}$, whereas, in CGP 45715A the diastereoisomeric configuration is required for potent $\mathrm{pLT}$ antagonism. The SK\&F compounds as well as LY 170680 also retain the acidic function equivalent to the carboxylic group in the eicosanoid backbone of $\mathrm{LTD}_{4}$. SK\&F 104353 is clinically the most advanced pLT analog and could be one of the first pLT antagonists to reach the market, if the problems with an irritant aerosol formulation can be resolved. The follow up compound SK\&F 106203 (the dehydroxy derivative of SK\&F 104353), although ten times less potent in vitro, has improved oral activity in comparison to SK\&F 104353. Accordingly, an oral formulation of SK\&F 106203 is being developed. The most potent antagonist of the pLT analog type CGP $45715 \mathrm{~A}$ is very active via the oral route of administration. However, in the guinea pig CGP 45715A is about three to four orders of magnitude more potent when applied as an aerosol (e.g. $30 \mathrm{ng} / \mathrm{kg}$ aerosol vs. $0.3 \mathrm{mg} / \mathrm{kg}$ p.o.), and thus an aerosol formulation is initially being evaluated clinically.

\section{Quinolines (Table 3)}

Around 1980, every pharmaceutical company involved in pLT antagonist re- 
Endoperoxide

Prostaglandin $G_{2}$

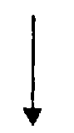

Prostaglandins

Prostacyclin

Thromboxane

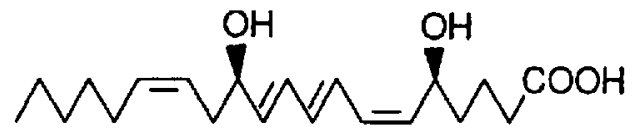

Leukotriene $\mathrm{B}_{4}\left(\mathrm{LTB}_{4}\right)$

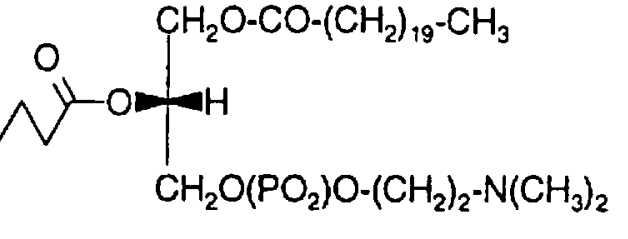

Phospholipase $A_{2}$<smiles>CCCCCC=CCC=CCC=CCC=CCCCC(=O)O</smiles>

Arachidonic acid
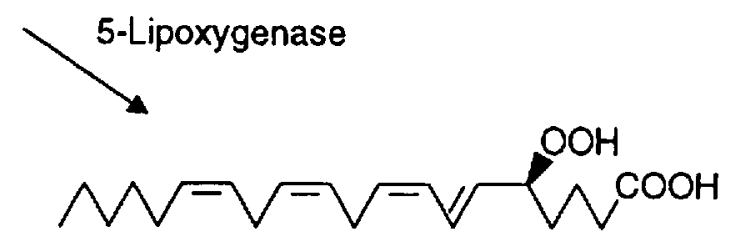

5-Hydroperoxy-eicosatetraenoic acid Dehydrase

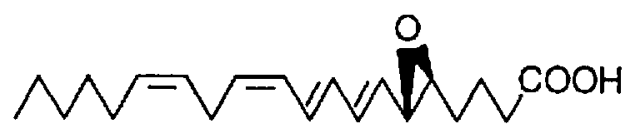

$\mathrm{LTA}_{4}$ Hydrolase

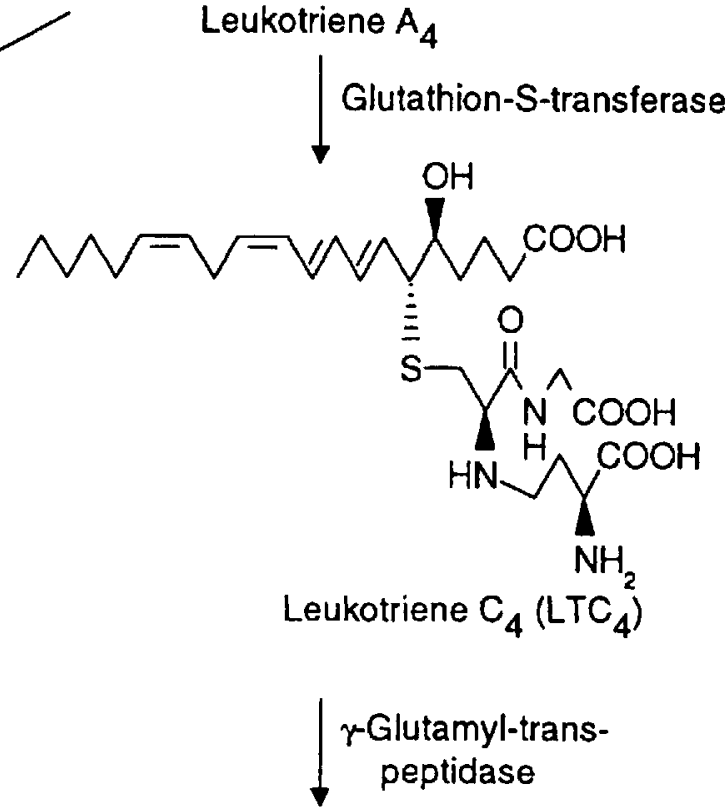<smiles>CCCCCC/C=C\C/C=C\C=C/C[C@@H](CSC[C@H](N)[C@H](O)C(=O)O)[C@H](O)CCCC(=O)O</smiles>

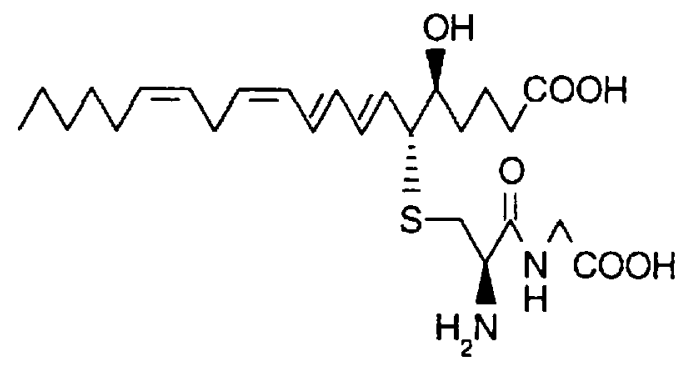

$\mathrm{LTE}_{4}$ 
Table 1. Hydroxyacetophenones: Analogs of FPL 55712

\begin{tabular}{|c|c|c|c|}
\hline Compound & State of Development & In vitro $L T$ Antagonism & Clinical Trials \\
\hline & $\begin{array}{l}\text { Phase II, aerosol: } \\
\text { suspended }\end{array}$ & $\begin{array}{l}\text { Inhibition of }\left[{ }^{3} \mathrm{H}\right]-\mathrm{LTD}_{4} \text { binding to } \\
\text { guinea pig lung membranes: } / C_{50}= \\
4 \mu \mathrm{M}[5] \text {. Inhibition of } \mathrm{LTD}_{4}-\mathrm{in}- \\
\text { duced guinea pig ileum }\left(\mathrm{pA}_{2}=7.33 \text { ) }\right. \\
\left.\text { lung strip ( } \mathrm{pA}_{2}=7.04\right) \text { and trachea } \\
\left(\mathrm{pA}_{2}=6.9\right) \text { contractions }[6] \text {. }\end{array}$ & $\begin{array}{l}\text { Limited clinical studies: Effective } \\
\text { against } \text { LTC }_{4} \text {-induced broncho- } \\
\text { constriction in two volunteers. No } \\
\text { effect against antigen-induced } \\
\text { bronchoconstriction in asthmatic } \\
\text { patients. No effect in chronic asth- } \\
\text { matics [6]. }\end{array}$ \\
\hline
\end{tabular}

(Industry standard)

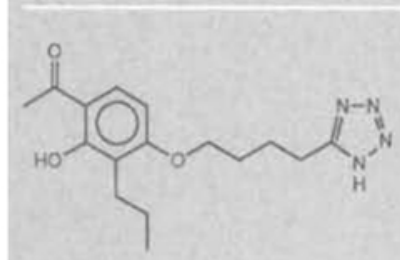

Tomelukast, LY 171883

(Lilly)
Phase II/III, oral; suspended
Inhibition of $\left[{ }^{3} \mathrm{H}\right]-\mathrm{LTD}_{4}$ binding to guinea pig lung membranes: $36 \%$ at $10 \mu \mathrm{M}$ [6]. Inhibition of $\mathrm{LTD}_{4-}$ induced guinea pig ileum contractions : $\mathrm{p} K_{\mathrm{B}}=7.2[7]$.
Long-term toxicity in female mice [8]. Effective against exogenously-administered LTD $_{4}$-induced bronchoconstriction. Attenuation of late-phase bronchospasm in allergen challenged asthmatics. Improvement of pulmonary function in patients with chronic, mild asthma [9].<smiles>CCCc1c(OCCCCc2nnn(CCCCc3nn[nH]n3)n2)ccc(C(C)=O)c1O</smiles>

Preclinical

LY 203647 (Lilly)
Phase II, aerosol: suspended
Antagonism of $\mathrm{LTD}_{4}$ - and $\mathrm{LTE}_{4}$ induced guinea pig ileum contractions: $\mathrm{p} K_{\mathrm{B}}=7.1$ and $7.4[10]$.
Selected for clinical evaluation in cardiovascular disorders thought tobeassociated withexcessivepLT production.<smiles>CCCc1c(OCCCS(=O)(=O)c2ccc(C(=O)CCC(=O)O)cc2)ccc(C(C)=O)c1O</smiles>

L-648051 (Merck Frosst)
Inhibition of $\left[{ }^{3} \mathrm{H}\right]-\mathrm{LTD}_{4}$ binding to guinea pig lung membranes: $K_{\mathrm{i}}=$ $6.2 \mu \mathrm{M}$ and antagonism of $\mathrm{LTD}_{4}$. induced guinea pig ileum contractions: $\mathrm{pA}_{2}=7.7[11]$.

Effective against exogenously-administered $\mathrm{LTD}_{4}$-induced bronchoconstriction. No protection against early and late asthmatic response or the deterioration in bronchial hyperresponsiveness after allergen challenge in asthmatic patients [12].<smiles>CCCc1c(OCCCSc2ccc(C(O)C(C)CC(=O)O)cc2)ccc(C(C)O)c1O</smiles>

Phase II, oral; suspended
Inhibition of $\left[{ }^{3} \mathrm{H}\right]-\mathrm{LTD}_{4}$ binding to guinea pig lung membranes: $K_{\mathrm{b}}=$ $0.4 \mu \mathrm{M}$ and antagonism of $\mathrm{LTD}_{4}$. induced guinea pig ileum contractions: $\mathrm{pA}_{2}=8.1$ [11].

Effective against exogenously-administered $\mathrm{LTD}_{4}$-induced bronchoconstriction. Minor protection against early bronchospasm and no protection against late bronchospasm in patients with mild asthma after antigen challenge [13].

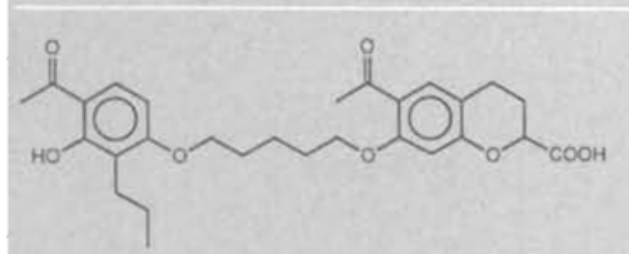

Phase I, aerosol; suspended

Phase I, aerosol: suspended
Inhibition of $\left[{ }^{3} \mathrm{H}\right]-\mathrm{LTD}_{4}$ binding to guinea pig lung membranes: $I C_{50}=$ $4 \mu \mathrm{M}$ and antagonism of $\mathrm{LTD}_{4}$ induced guinea pig trachea contractions: $\mathrm{pA}_{2}=6.6[5]$.
Induction of early and late bronchospasm in mildly asthmatic patients $[14]$.

Ablukast, Ro 23-3544

(F. Hoffmann-La Roche AG)<smiles>CCCc1c(OCCCOc2cc(NC(O)C(N)N3NCNN3)c(C)cc2Cl)ccc(C(C)=O)c1O</smiles>

Inhibition of $\left[{ }^{3} \mathrm{H}\right]-\mathrm{LTD}_{4}$ binding to Irritant formulation. guinea pig lung membranes: $I C_{50}=$ $1 \mu \mathrm{M}[5]$ and antagonism of $\mathrm{LTD}_{4}$. induced guinea pig ileum contractions: $\mathrm{pA}_{2}=8.2$ [15]. 
Table I (cont.)

State of Development $\begin{aligned} & \text { In vitro LT Antagonism } \\ & \text { Phase III, oral }\end{aligned}$
$\begin{aligned} & \text { Antagonism of } \mathrm{LTD}_{4} \text {-induced } \\ & \text { guinea pig ileum }\left(I C_{50}=0.11 \mu \mathrm{M}\right) \\ & \text { and trachea }\left(I C_{50}=0.16 \mu \mathrm{M}\right) \text { con- } \\ & \text { tractions [16]. }\end{aligned}$
$\begin{aligned} & \text { Moderate improvements against } \\ & \text { tion and aspirin-induced asthma in } \\ & \text { asthmatic patients }[17] \text {. }\end{aligned}$
AS-35 (Tokyo Tanabe)

Table 2. Peptidoleukotriene Analogs

Compound
$\begin{aligned} & \text { Phase II/III, aerosol; Inhibition of }\left[{ }^{3} \mathrm{H}\right]-\mathrm{LTD}_{4} \text { binding to } \\ & \text { on hold } \\ & \text { Clinical trials halted } \mathrm{nM} \text { and antagonism of } \mathrm{LTD}_{4} \text {-in- } \\ & \text { due to an irritant ex- duced guinea pig trachea contrac- } \\ & \text { cipient [19]. }\end{aligned}$

Clinical Trials

Effective against exogenously-administered $\mathrm{LTD}_{4}$-induced, allergen and exercise induced bronchoconstriction in asthmaties (including late-phase response) [21]. Effective against aspirin-induced asthma [22].

SK\&F 104353 (SmithKline

Beecham)

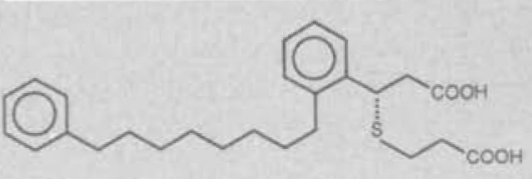

Phase II, oral

Inhibition of $\left[{ }^{3} \mathrm{H}\right]-\mathrm{LTD}$, binding to guinea pig lung membranes: $K_{\mathrm{i}}=$ $19.4 \mathrm{nM}$ and antagonism of $\mathrm{LTD}_{4}^{-}$

Effective against $\mathrm{LTD}_{4}$-induced bronchoconstriction in healthy volunteers [24]. tractions: $\mathrm{pA}_{2}=7.6[23]$.

SK\&F S-106203 (SmithKline

Beecham)

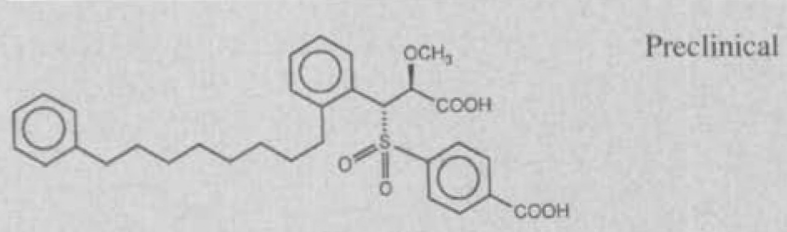

Inhibition of $\left[{ }^{3} \mathrm{H}\right]-\mathrm{LTD}_{4}$ binding to

Clinical candidate. guinea pig lung membranes: $K_{i}=$ $1.28 \mathrm{nM}$ and antagonism of $\mathrm{LTD}_{4}-$ induced guinea pig trachea contractions: $\mathrm{p} K_{\mathrm{B}}=8.3[25]$.

SK\&F 107310 (SmithKline

Beecham)

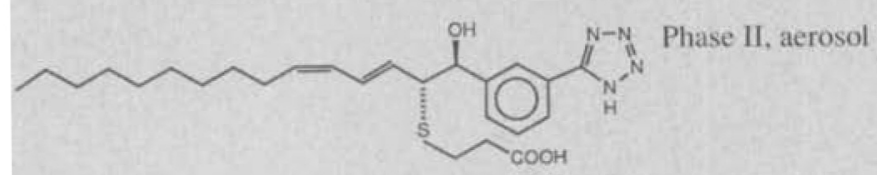

Sulukast, LY 170680 (Lilly)
Antagonism of $\mathrm{LTD}_{4}$-induced guinea pig trachea $\left(\mathrm{pA}_{2}=8.1\right)$ and ileum $\left(\mathrm{pA}_{2}=8.7\right)$ contractions [26].
Effective against $\mathrm{LTD}_{4}$-induced bronchoconstriction in healthy volunteers [26].

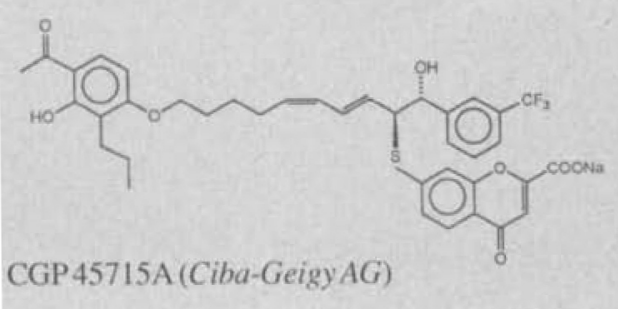

Phase II, aerosol

Inhibition of $\left[{ }^{3} \mathrm{H}\right]-\mathrm{LTD}_{4}$ binding to guinea pig lung membranes: $K_{\mathrm{i}}=$ $2.2 \mathrm{nM}$ and antagonism of $\mathrm{LTD}_{4}$ induced guinea pig ileum contractions: $\mathrm{pA}_{2}=10.1[27]$.
Effective against $\mathrm{LTD}_{4}$-induced bronchoconstriction in healthy volunteers. 


\section{Table 3. Quinolines}

\begin{tabular}{|c|c|c|c|}
\hline Compound & State of Development & In vitro $\mathrm{LT}$ Antagonism & Clinical Trials \\
\hline & $\begin{array}{l}\text { Phase I, oral; } \\
\text { suspended }\end{array}$ & $\begin{array}{l}\text { Inhibition of }\left[{ }^{3} \mathrm{H}\right]-\mathrm{LTD}_{4} \text { binding to } \\
\text { guinea pig lung membranes: } K_{1}=35 \\
\text { nMand antagonism of } \mathrm{LTD}_{4} \text {-induced } \\
\text { guineapig trachea contractions: } \mathrm{pA}_{2} \\
=7.62[28] \text {. }\end{array}$ & $\begin{array}{l}\text { No clinical data available. } \\
\text { Development discontinued follow- } \\
\text { ing toxicity problems in monkeys } \\
{[29] \text {. }}\end{array}$ \\
\hline
\end{tabular}

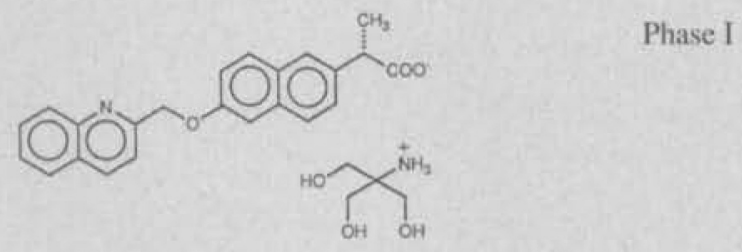

Wy-50295 (Wyeth-Ayerst)
5-Lipoxygenase inhibitor/pL anta- No clinical data available. gonist. In vitro inhibition of LT biosynthesis: $I C_{50}=0.055 \mu \mathrm{M}$ to 1.79 $\mu \mathrm{M}$ (variouscells). Inhibition of [ $\left.{ }^{3} \mathrm{H}\right]$ $\mathrm{LTD}_{4}$ binding to guinea pig lung membranes: $K_{1}=2.8 \mu \mathrm{M}$ and antagonism of $\mathrm{LTD}_{4}$-induced guinea pig tracheacontractions: $\mathrm{pA}_{2}=6.06[30]$.<smiles>CCCCCC(O)c1cccc(OCc2ccc3ccccc3n2)c1</smiles>

REV-5901 (Revlon)
Phase I, oral: suspended
Phase II, oral; suspended
5-Lipoxygenase inhibitor/pLT antagonist. Inhibition of 5-lipoxygenase in rat neutrophils: $I C_{50}=0.12 \mu \mathrm{M}$. Antagonism of $\mathrm{LTC}_{4}$-induced guinea pig lung parenchymal strip contractions: $I C_{S 0}=3.6 \mu \mathrm{M}[31]$.
No effect against LTD $_{4}$-induced bronchoconstriction in healthy volunteers [32].

Inhibition of $\left[{ }^{3} \mathrm{H}\right]-\mathrm{LTD}_{4}$ binding to Smalleffect against $\mathrm{LTD}_{4}$-induced guinea pig lung membranes: $I C_{50}=$ bronchoconstriction in asthmatic $23 \mathrm{nM}$ and antagonism of $\mathrm{LTD}_{4^{-}}$humans [34]. induced guinea pig trachea contractions: $\mathrm{pA}_{2}=8.7$ [33].

SR $2640($ Leo $)$<smiles>COC(=O)CCSC(SCCC(=O)O)c1cccc(/C=C/c2ccc3ccc(Cl)cc3n2)c1</smiles>

Verlukast. MK-679

Racemate: MK-571 (Merck Frosst)
Phase II/III, intravenous, oral \& aerosol; suspended
Inhibition of $\left[{ }^{3} \mathrm{H}\right]-\mathrm{LTD}_{4}$ binding to MK 571 : Effective against exogeguinea pig lung membranes: $I C_{50}=$ nously-administered $L^{2} \mathrm{TD}_{4}$-in$3.1 \mathrm{nM}$ and antagonism of $\mathrm{LTD}_{4^{-}}$duced bronchoconstriction. Inhiinduced guinea pig trachea contrac- bition of early and late asthmatic tions: $\mathrm{p} K_{\mathrm{B}}=8.8[35]$. responses after antigen challenge in asthmatic patients. Attenuation of exercise-induced bronchoconstriction in asthmatics. Beneficial effects on baseline pulmonary function in moderately severe asthmatic subjects [36]. Suspension of development due to tolerability problems [37].

\section{$\mathrm{RG}_{12525}$ \\ (Rhone-Poulenc Rorer) \\ Phase II, oral<smiles>O=c1cc(-c2nnn[nH]2)oc2cc(OCc3cccc(OCc4ccc5ccccc5n4)c3)ccc12</smiles>

RG 12553 (Rhone-Poulenc Rorer)
Inhibition of $\left[{ }^{3} \mathrm{H}\right]-\mathrm{LTD}_{4}$ binding to Modest activity against $\mathrm{LTD}_{4}$-inguinea pig lung membranes: $K_{\mathrm{i}}=3$ duced bronchoconstriction in asthnMandantagonism of $\mathrm{LTC}_{4^{-}}, \mathrm{LTD}_{4^{-}}$matics [39]. Attenuation of antior $\mathrm{LTE}_{4}$-induced guinea pig paren- gen-induced bronchoconstriction chymal strip contractions: $K_{\mathrm{B}} c a .3 \mathrm{nM}[38]$. [40a] and improvement of lung function in asthmatic patients [40b].

Inhibition of $\left[{ }^{3} \mathrm{H}\right]-\mathrm{LD}_{4}$ binding to guinea pig lung membranes: $K_{i}=0.1$ nMand antagonism of $\mathrm{LTD}_{4}$-induced guinea pig parenchymal strip contractions: $/ C_{50}=0.5 \mathrm{nM}[41]$.<smiles>O=C(c1ccccc1)c1cc(F)ccc1Cn1nnc(-c2cccc(/C=C/c3ccc4ccc(Cl)cc4n3)c2)n1</smiles>

Antagonism of $\mathrm{LTD}_{4}$-induced guinea pig ileum contractions: $\mathrm{p} K_{\mathrm{B}}=9.1[42]$. 
search, produced analogs of FPL 55712 . Now, around ten years later pLT antagonists of the quinoline type, first synthesized by Wyeth-Ayerst, are the preferred target of the pharmaceutical industry. In general, simple synthesis, chemical stability, high in vitro potency and, compared to FPL 55712 analogs, good oral activity are the reasons for the attractiveness of quinolines. In addition, many compounds have the additional property of being LT biosynthesis inhibitors.
The 2-substituted quinoline residue plays an equally important role for these pLT antagonists as did the hydroxyacetophenone residue in analogs of FPL 55712. In each structural class, these groups are absolutely essential to achieve potent pLT antagonist activity. Quinoline pLT antagonists share the following structural principles: the quinoline nucleus is attached via a two-atom spacer to an aromatic residue linked to an acidic function. Although the clinical development of Wy-
48252 and MK- 679 had to be stopped due to toxicity problems, quinolines are nevertheless a promising source for clinically useful pLT antagonists.

\section{Thiazoles (Table 4)}

The thiazole pLT antagonists, discovered by Mitsubishi, are structurally related to the quinolines, in that the thiazole residue can be regarded as a replacement of

Table 4. Thiazoles

\begin{tabular}{|c|c|c|c|}
\hline Compound & State of Development & In vitro $L T$ Antagonism & Clinical Trials \\
\hline MCI-826 (Mitsubishi) & Phase I & $\begin{array}{l}\text { Inhibition of }\left[{ }^{3} \mathrm{H}\right]-\mathrm{LTD}_{4} \text { binding } \\
\text { to guinea pig lung membranes: } \\
I C_{50}=7 \mathrm{nM} \text { and antagonism of } \\
\mathrm{LTD}_{4} \text {-induced guinea pig ileum } \\
\text { contractions: } / C_{50}=0.56 \mathrm{nM} \text {. }\left(I C_{50}\right. \\
\text { values determined at Ciba-Gei- } \\
\text { gy.) }[43]\end{array}$ & No clinical data available. \\
\hline $\begin{array}{l}\text { Ro 24-5913 } \\
\text { (F. Hoffmann-La Roche } A G)\end{array}$ & Phase I & $\begin{array}{l}\text { Inhibition of }\left[{ }^{3} \mathrm{H}\right]-\mathrm{LTD}_{4} \text { binding } \\
\text { to guinea pig lung membranes: } \\
I C_{50}=6.4 \mathrm{nM} \text { and antagonism of } \\
\text { LTD } \\
\text { contractions: } \mathrm{pA}_{2}=9.6[44] \text {. }\end{array}$ & No clinical data available. \\
\hline
\end{tabular}

Table 5. Indazole and Indoles

\begin{tabular}{|c|c|c|c|}
\hline Compound & State of Development & In vitro $\mathrm{LT}$ Antagonism & Clinical Trials \\
\hline & Preclinical & $\begin{array}{l}\text { Inhibition of }\left[{ }^{3} \mathrm{H}\right]-\mathrm{LTD}_{4} \text { binding } \\
\text { to guinea pig lung membranes: } K_{\mathrm{i}} \\
=0.28 \mathrm{nmandantagonismof} \mathrm{LTE}_{4}- \\
\text { induced guinea pig tracheal strip } \\
\text { contractions: } \mathrm{p} K_{\mathrm{B}}=10.26[45] \text {. }\end{array}$ & $\begin{array}{l}\text { Poor bioavailability following oral } \\
\text { administration in guinea pigs, rats, } \\
\text { and dogs. Pharmacological tool } \\
\text { [46]. }\end{array}$ \\
\hline ICI $198615(I C I)$ & & & \\
\hline ICI $204219(I C I)$ & $\begin{array}{l}\text { Phase III, } \\
\text { oral \& aerosol }\end{array}$ & $\begin{array}{l}\text { Inhibition of }\left[{ }^{3} \mathrm{H}\right]-\mathrm{LTD}_{4} \text { binding } \\
\text { to guinea pig lung membranes: } K_{\mathrm{i}} \\
=0.34 \mathrm{nM} \text { and antagonismof } \mathrm{LTE}_{4} \\
\text { induced guinea pig tracheal strip } \\
\text { contractions: } \mathrm{p} K_{\mathrm{B}}=9.67[47] \text {. }\end{array}$ & $\begin{array}{l}\text { Effective against exogenously-ad- } \\
\text { ministered } \mathrm{LTD}_{4} \text {-induced broncho- } \\
\text { constriction. } \\
\text { Effective against allergen- }[48] \text { or } \\
\text { exercise- [49] induced broncho- } \\
\text { constriction in asthmatics. Attenu- } \\
\text { ation of allergen-induced airway } \\
\text { hyperreactivity [48b]. Improve- } \\
\text { ment of lung function in asthmatic } \\
\text { patients [50]. }\end{array}$ \\
\hline
\end{tabular}

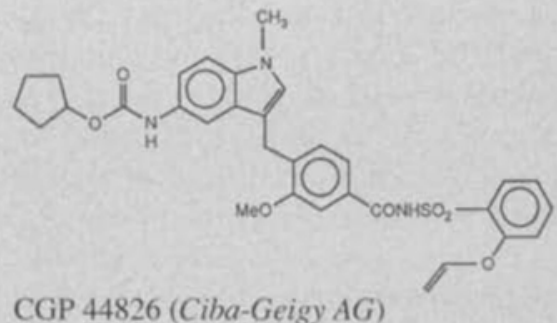

Preclinical,

oral \& aerosol
Antagonism of $\mathrm{LTD}_{4}$ - and $\mathrm{LTE}_{4}-$ induced guinea pig ileum contractions: $I C_{s_{0}}=0.56 \mathrm{nM}$ and $0.59 \mathrm{nM}$ respectively. Antagonism of pLT induced guinea pig lung strip contractions: $\mathrm{pA}_{2} \mathrm{LTD}_{4}=7.9 ; \mathrm{pA}_{2}$ $\mathrm{LTE}_{4}=8.7[51]$ 


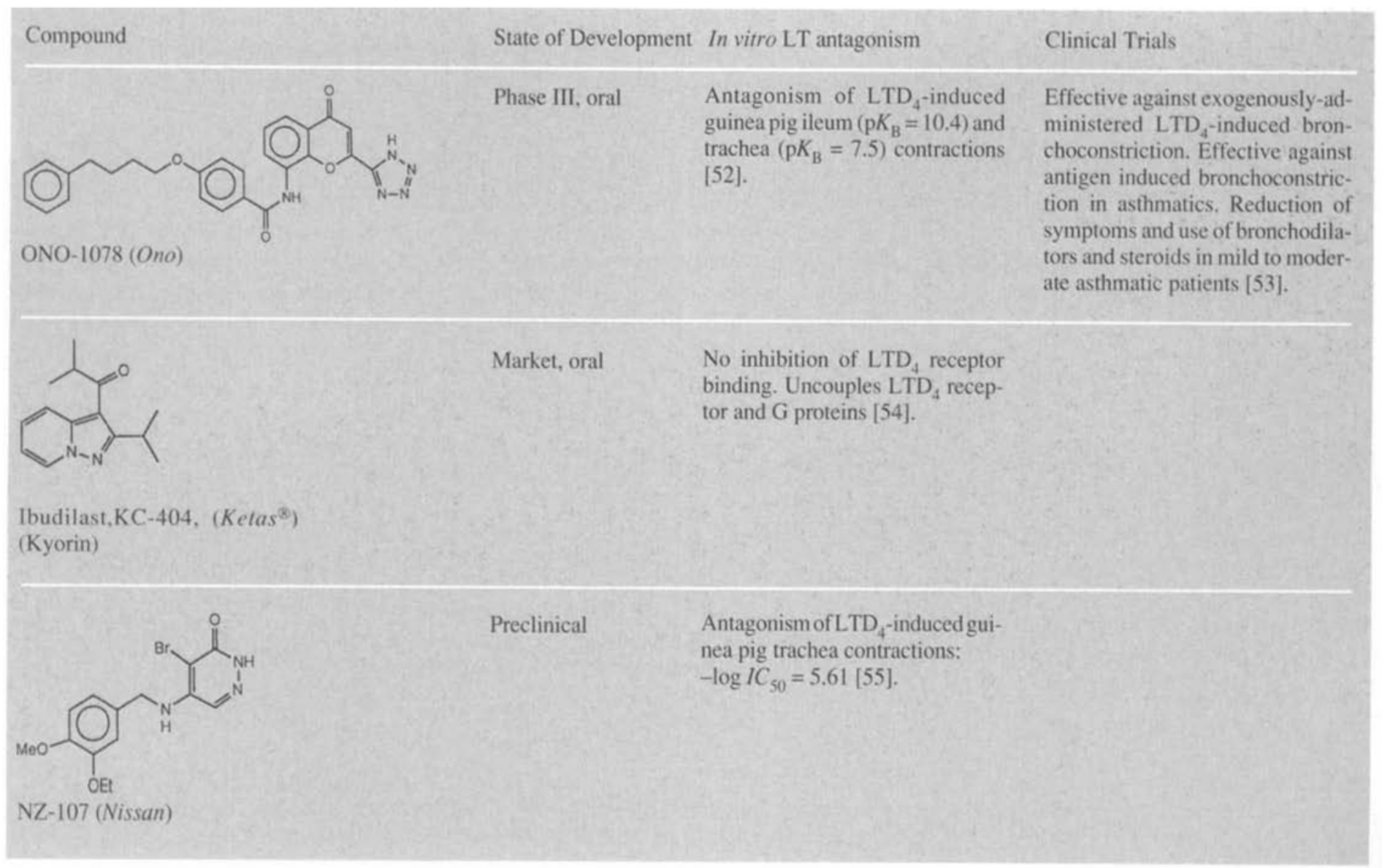

the quinoline nucleus. With respect to oral potency, bioavailability, and duration of action in guinea pigs, Ro 24-5913 is one of the most interesting pLT antagonists known. If these findings can be translated into patients, Ro 24-5913 will be an interesting clinical candidate.

\section{Indazoles and Indoles (Table 5)}

The substituted indazole and indole derivatives ICI 198615 and ICI 204219 are among the most potent $\mathrm{LTD}_{4}$ antagonists known to date. Structural similarities between a series of FPL 55712 analogs and a series of pLT analogs led to the synthesis of this innovative class of compounds. The (cyclopentyloxycarbonyl)amino-substituted indazole/indole residue is a mimic of the hydroxyacetophenone part of FPL 55712, and the para-benzylbenzoic-acid mimics the conjugated triene system of the pLTs. Although ICI 198615 and ICI 204219 are equipotent in vitro, ICI 204219 was preferred for development due to much better oral activity in vivo. ICI 204219 is one of the most advanced pLT antagonists in the clinic. Successful phase II/III studies justify the hope that ICI 204219 will be the first marketed pLT antagonist.
ICI 198615 is a valuable pharmacological tool. The tritiated molecule has been used for investigations of pLT receptors.

\section{Miscellaneous Structures (Table 6)}

ONO-1078 is well advanced in clinical development and is reported to show beneficial effects in asthmatic patients. The structure of ONO-1078 can be derived from FPL 55712, although the hydroxyacetophenone residue is replaced by a $\mathrm{Ph}$ group.

Ibudilast $\left(\mathrm{KC}-404, \operatorname{Ketas}^{\circledR}\right)$ is the only 'pLT antagonist' on the market - in Japan. The compound does not bind to the $\mathrm{LTD}_{4}$ receptor and has weak functional $\mathrm{pLT}^{4}$ antagonist properties. The antiasthmatic activity observed in man may be attributed to a number of other biological activities of this molecule.

\section{Conclusion}

The mainstay of current asthma therapy are still bronchodilators which treat the acute asthma attack. $\beta$-Agonists and xanthines are the drugs currently used to relieve the bronchoconstriction. However, these medications probably have little or no effect on airway inflammation and the late phase bronchoconstriction seen in many asthmatics. Inflammatory processes, likely to be responsible for bronchial hyperresponsiveness, can only be treated by inhaled or oral corticosteroids. 'Mast cell stabilizers' like disodium cromoglycate, which are said to prevent inflammatory mediator release, can be used as a prophylactic treatment only in mild to moderate asthmatics. Shortcomings of bronchodilators and side effects of corticosteroids require new approaches in the treatment of asthmatic diseases, especially the inflammatory response in the asthmatic airway. Since pLTs are mediators of bronchoconstriction and bronchial hyperresponsiveness, pLT antagonists should be useful therapeutic agents for the treatment of asthma and related conditions. Clinical results with highly potent pLT antagonists, such as SK\&F 104353, Verlukast, ICI 204219, and ONO-1078, appear to confirm this hypothesis. The beneficial effects obtained in asthmatic patients include protection against allergen or exercise induced early and late phase bronchoconstriction, attenuation of antigen-provoked airway hyperreactivity and bronchodilation. Further clinical trials are needed to fully explore the potential of pLT antagonists in asthma. The pLTs have been proposed to be involved in a variety of other diseases and the availability of 
potent, selective antagonists in clinical development will allow an exploration of the role of pLTs in such diseases and, potentially, markedly expand the therapeutic profile of this class of drugs. Today, it seems certain, at least that $\mathrm{pLT}$ antagonists will find their place in the management of asthmatic diseases.

Received: June 29, 1992

[1] 'Bioactive Molecules, Vol, 11: Leukotrienes and Lipoxygenases Chemical, Biological and Clinical Aspects',Ed.J. Rokach, Elsevier, Amsterdam, 1989.

|2| a) J.H. Musser, Drug News Perspect. 1989 , 2, 202; b) D.W. Snyder, J.H. Fleisch, Annu. Rev.Pharmacol.Toxicol. 1989,29, 123; c) A. Shaw, R.D. Krell, J. Med. Chem. 1991. 34, 1235; d) A. von Sprecher, A. Beck, A Sallmann, W. Breitenstein, H.R. Wiestner, S. Kimmel, G.P. Anderson, N. Subramanian, M.A. Bray, Drugs Future 1991, 16, 827; e) A. von Sprecher, A. Sallmann, A. Beck, W. Breitenstein, H.R. Wiestner, S. Kimmel, W.H. Anderson, G.P. Anderson, N. Subramanian, M.A. Bray, in 'Trends in Medicinal Chemistry', Eds. S. Sarel, R. Mechoulam, and I. Agranat, Blackwell, Oxford, 1992, p. 219.

[3] J. Augstein, J.B. Farmer, T.B. Lee, P. Sheard, M.L. Tattersall, Nature (London), New Biol. 1973, 245, 215.

[4] a) S. Hammarström, R.C. Murphy, B. Samuelsson, P.A. Clark, C. Mioskowski, E.J. Corey, Biochem. Biophys. Res. Commun. 1979, 9/, 1266; b) E.J. Corey, D.A. Clark, G. Goto, A. Marfat, C. Mioskowski, B Samuelsson, S. Hammarström, I. Am. Chem. Soc. 1980, 102, 1436.

[5] N. Cohen, G. Weber, B.L. Banner, R.J. Lopresti, B. Schaer, A. Focella, G.B. Zenchoff, A.-M. Chiu, L. Todaro, M. O'Donnell, A.F. Welton, D. Brown, R. Garippa, H. Crowley, D.W. Morgan, $J$ Med. Chem. 1989, 32, 1842.

[6] J.R. Bantick, M.C. Holroyde, T.B. Lee, P. Sheard, in 'Development of Anti-asthma Drugs', Eds. D.R. Buckle and H. Smith, Butterworths, London, 1984, p. 133.

[7] W.S. Marshall, T. Goodson, G.J. Cullinan, D. Swanson-Bean, K.D. Haisch, L.E. Rinkema, J.H. Fleisch, J. Med. Chem. 1987, 30, 682 .

[8] A.M. Bendele, D.M. Hoover, R.B.L. van Lier, P.S. Foxworthy, P.I. Eacho, Fundam. Appl. Toxicol. 1990, 15, 676.

$19]$ J.H. Fleisch, M.L. Cloud, W.S. Marshall, Ann. N. Y. Acad. Sci. 1988, 524, 356.

[10] W.S. Marshall, S.K. Sigmund, C.A. Whitesitt, S.L. Lifer, C.R. Roman, L.E. Rinkema, R.A. Hahn, J.H. Fleisch, Agents Actions 1989, 27, 309

[11] R.N. Young, Drugs Future 1988, 13, 745

[12] E.H. Bel, M.C. Timmers, J.H. Dijkman, E.G. Stahl, P.J. Sterk, J. Allergy Clin. Immunol. 1990, 85, 1067.

[13] J.R. Britton, S.P. Hanley, A.E. Tattersfield, J. Allergy Clin. Immunol. 1987, 79, 811.

[14] D. Pace, M. Molle, J. Massarella, B. Pauli, J. Allergy Clin. Immunol. 1989, 83, 205.
[15] M.A. Bray, A. Beck, P. Wenk, F. Märki, N. Subramanian, U. Niederhauser, M. Kuhn, A. Sallmann, Adv. Prostaglandin Thromboxane Leukotriene Res. 1987, 17A, 526.

[16] K. Tomioka, T. Yamada, T. Mase, H. Hara, K. Murase, Arzneim.-Forsch. 1988, 38, 682.

[17] K. Tomioka, T. Yamada, T. Mase, R. Tsuzuki, H. Hara, K. Murase, W.M. Abraham, 2nd International Conference on Leukotrienes \& Prostanoids in Health and Disease, October 9-14, 1988, Jerusalem, Israel, abstract book, p. 50 .

[18] K. Yasui, E. Ohkawa, H. Yamamura, S. Kohno, M. Horiba, K. Inoue, K. Ohata, Jpn. J. Pharmacol. 1990, 52, (Suppl. I) 91P, abstract 0-058.

[19] Scrip 1989, 1392, 24

[20] D.W.P. Hay, J.F. Newton, T.J. Torphy, J.G. Gleason, Drugs Future 1990, 15, 240.

[21] T.J. Torphy, I. Faiferman, J.G. Gleason, R.F. Hall, M.A. Lewis, C. Broom, H.M. Helfrich, J.F. Newton, D.W.P. Hay, Ann. N. Y. Acad. Sci. 1991, 629, 157.

[22] P.E. Christie, C.M. Smith, T.H. Lee, Am. Rev. Respir. Dis. 1991, 144, 957

[23] D.W.P. Hay, R.M. Muccitelli, L.M. Vickery-Clark, L.S. Novak, R.R. Osborn, J.G. Gleason, L.-A.P. Yodis, C.M. Saverino, R.D. Eckardt, H.M. Sarau, M.A. Wasserman, T.J. Torphy, J.F. Newton, Pulm. Pharmacol. 1991, 4, 177

[24] L.J. Mansell, J. Evans, S. Yenlet, N. Moore, J. Laroche, S. Barrow, Pharm. Res. 1991, 8 , No. 10, Suppl., 249

[25] D.W.P. Hay, M.A. Luttmann, R.M. Muccitelli, L.B. Novak, R.R. Osborn, D.C. Underwood, J.J.Foley, D.B. Schmidt, H.M. Sarau, L.P. Yodis, J.F. Newton, J.G. Gleason, J.S. Frazee, T.J. Torphy, Am.Rev. Respir. Dis. 1992, 145 (4, part 2), A287.

[26] S.R. Baker, J.R. Boot, R. Lucas, G. Wishart, Drugs Future 1991, 16, 432.

[27] a) A. von Sprecher, A. Beck, A. Sallmann, W. Breitenstein, H. Wiestner, J. Brokatzky-Geiger, K. Eisler, R. Gamboni, L. Rösslein, G. Schlingloff, N.C. Cohen, L.H. Bach, G.P. Anderson, N. Subramanian, M.A. Bray, Med. Chem. Res. 1991, $I$, 195; b) M.A. Bray, W.H. Anderson, N. Subramanian, U. Niederhauser, M. Kuhn, M. Erard, A. von Sprecher, Adv. Prostaglandin Thromboxane Leukotriene Res. 1991 2IB, 503.

[28] J.H. Musser, A.F. Kreft, R.H.W. Bender D.M. Kubrak, R.P. Carlson, J. Chang, J.M Hand, J. Med. Chem. 1989, 32, 1176.

[29] Scrip 1991, 1613,26.

[30] B.M. Weichman, J.W. Berkenkopf, D. Grimes, R.J. Heaslip, R.J. Sturm, J.Y. Chang, Adv. Prostaglandin Thromboxane Leukorriene Res. 1991, 2 /A, 477.

[31] J.H. Musser, U.R. Chakraborty, S. Sciortino, R.J. Gordon, A. Khandwala, E.S. Neiss, T.P. Pruss, R. Van Inwegen, I. Weinryb, S.M. Coutts, J. Med. Chem. 1987, 30, 96.

[32] J.M. Evans, N.C. Barnes, P.J. Piper, J.F. Costello, Brit. J. Clin. Pharmacol. 1988, 25, 111 P-112P.

[33] I. Ahnfelt-Rønne, D. Kirstein, C. Kaergaard-Nielsen, Eur. J. Pharmacol. 1988, $155,117$.

[34] L. Frolund, F. Madsen, J. Nielsen, Allergy $1991,46,355$

[35] T.R. Jones, R. Zamboni, M. Belley, E. Champion, L. Charette, A.W. Ford-Hutchinson, J.-Y. Gauthier, S. Leger, A. Lord, P.
Masson, C.S. McFarlane, K.M. Metters, C. Pickett, H. Piechuta, R.N. Young, Can. J. Physiol. Pharmacol. 1991, 69, 1847.

[36] D.J. Margolskee, Ann. N. Y. Acad. Sci. $1991,629,148$

[37] Scrip 1991, I6I2, 23.

[38] F.-C. Huang, Drugs Future 1991, 16, 1121.

[39] I. Wahedna, A.S. Wisniewski, A.E. Tattersfield, Br.J.Clin. Pharmacol. 1991, 32 , 512.

[40] a) J.E. Fish, M.S. Gillen, J.A. Smith, $J$. Allergy Clin. Immunol. 1992, 89, No.I, Pt.2, 236; b) M. Welch, G. Feiss, H. Nelson, B. Paull, J. Smith, R. Tobey, ibid. 1992, 89, No. 1, Pt. 2, 236, abstract 366.

[41] F.-C. Huang, R.A. Galemmo, Jr., G.B.Poli, K.S. Learn, M.M. Morrissette, W.H. Johnson, Jr., W.P. Dankulich, H.F. Campbell, G.W. Carnathan, R.G. Van Inwegen, $J$. Med. Chem. 1991, 34, 1704.

[42] J.S. Sawyer, R.F. Baldwin, L.E. Rinkema, C.R. Roman, J.H. Fleisch, I. Med. Chem. $1992,35,1200$.

[43] N. Tsuzuike, H. Kondo, S. Ito, M. Saga, H. Tsujimori, K. Nagasawa, S. Kohno, M. Horiba, K. Inoue, K. Ohata, Jpn. J. Pharmacol. 1988, 46, (Suppl.) 227 P., abstract P.407.

[44] M. O'Donnell, H.J. Crowley, B. Yaremko, N. O'Neill, A.F. Welton, J. Pharmacol. Exp. Ther. 1991, 259, 751.

[45] Y.K. Yee, P.R. Bernstein, E.J. Adams, F.J. Brown, L.A. Cronk, K.C. Hebbel, E.P. Vacek, R.D. Krell, D.W. Snyder, J. Med. Chem. 1990, 33, 2437.

[46] R.D. Krell, Pulm. Pharmacol. 1989, 2, 27.

[47] V.G. Matassa, T.P. Maduskuie, Jr., H.S. Shapiro, B. Hesp, D.W. Snyder, D. Aharony, R.D. Krell, R.A. Keith, J. Med. Chem. 1990, 33, 1781 .

[48] a) R.A. Nathan, W.W. Storms, S.F. Bodman, M.C. Minkwitz, M. Glass, J. Allergy Clin. Immunol 1991, 87, Pt. 2, 256; b) I. K. Taylor, K.M. O'Shaughnessy, R.W. Fuller, C.T. Dollery, Lancet 1991, 337, 690.

[49] J.P. Finnerty, R. Wood-Baker, H. Thomson, S.T. Holgate, Am. Rev. Resp. Dis. $1992,145,746$.

[50] K.P. Hui, N.C. Barnes, Lancet 1991, 337, 1062

[51] a) U. Niederhauser, G.P. Anderson, $M$. Kuhn, P. Reissbrodt, A. Sallmann, M. Gerspacher, A. von Sprecher, M.A. Bray, Presented at the 8th International Conference on Prostaglandins and Related Compounds, July 26-31, Montreal, Canada, 1992, Abstr.; b) A. Sallmann, W. Meyer, to Ciba-Geigy AG, 1991, Eur. Pat. Appl. EP 455596.

[52] Drugs Future 1988, 13, 317 .

[53] T. Nakagawa, Y. Mizushima, A. Ishii, F. Nambu, M. Motoishi, Y. Yui, T. Shida, T. Miyamoto, Ad1'. ProstaglandinThromboxane Leukotriene Res. 1991, 2lA, 465.

[54] S. Etoh, M. Ohashi, A. Bab, H. Iwata, Brit. J. Pharmacol. 1990, 100, 564.

[55] M. Hibi, K. Shikada, T. Iwama, A. Yamamoto, M. Sakashita, S. Tanaka, Jpn. J. Pharmacol. 1989, 5l, 411. 